DISTANT THUNDER

\section{Geologist and science writer Nina Morgan celebrates the work of a woman who laid down her scientific life to fight on the Home Front}

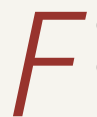

or lovers of graptolites, the names of Gertrude Elles [1872-1960] and Ethel Wood [1871-1946], both talented geologists and lifelong friends, will always be remembered for their 18 years of meticulous work on the mammoth Monograph of British Graptolites. The tome was edited by Charles Lapworth [18421920] and published in parts from 1901 until 1918. Elles was responsible for much of the text, and Wood for the outstanding illustrations.

As Elles noted, “... while the inspiration of that work in almost every detail was Lapworth's, much of the 'spade work' fell upon his two subordinates and it was often heavy ... Much of this work was carried out together and though it was strenuous the congenial companionship of those days of field work is a treasured memory."

The two met at Newnham College, Cambridge in 1891 where, Elles recalled, "... we attended geological classes and in our vacations on bicycles or on foot visited and studied many localities of special geological interest." In 1919, both were among the first group of women admitted as Fellows of the Geological Society.

\section{Women's work}

Ironically, both were considered suitable to work on the Monograph because of their gender. Women, it was then believed, were endowed with a high capacity for drudgery; were happy to seek knowledge for its own sake; would be satisfied with "the gratitude of future, if not present generations"; and would not necessarily expect financial gain or immediate academic recognition.

Nevertheless, both Elles and Wood also published important papers while working on the Monograph, for which each received recognition from the Geological Society of London. Elles was

\title{
A casualty of war
}

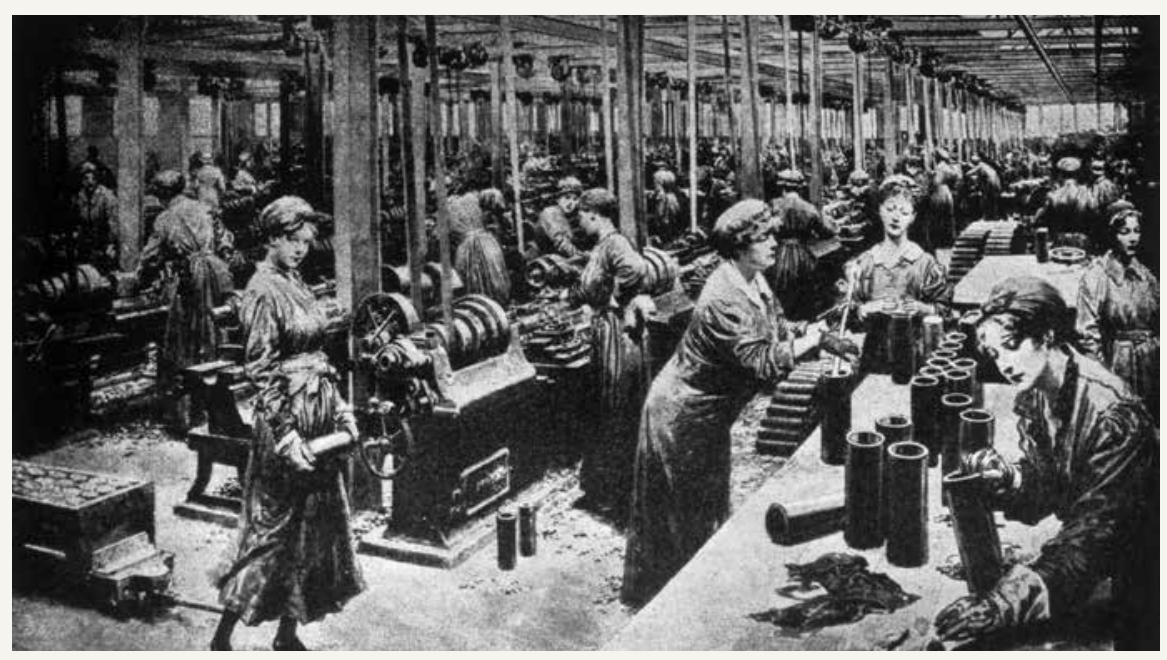

awarded the Lyell Fund in 1900 "to encourage her in further research" and Wood was awarded the Wollaston Fund for her paper on the Lower Ludlow graptolite fauna, published in the Quarterly Journal of the Geological Society in 1900. Both women also had academic careers.

\section{Wartime work}

Elles rose through the academic ranks in Cambridge University to become, in 1936, the first female University Reader in Geology. Meanwhile, Wood, who was elected an associate of Newnham College, was awarded a Doctor of Science (D.Sc.) from Birmingham University in 1906. In the same year, Wood married physics lecturer Gilbert Shakespear and relinquished her post at Birmingham, but continued to work on the Monograph.

However, when the First World War began, Wood's life changed completely. As Elles recalled, "she was drawn into public life by her deep concern for the welfare of the disabled soldiers, and from 1915 onwards she worked untiringly on their behalf to secure adequate pensions, treatment and training for discharged Service-men". Wood helped to found the Association of War Pension Committees in London and, among other things, was appointed a member of the Special Grants Committee of the Ministry of
Pensions in 1917. She was awarded an MBE in 1918 for her wartime work, and in 1920 became a Dame.

That same year she was awarded the Murchison Medal, and the president of the Geological Society, George William Lamplugh [1859-1926] expressed the hope that she would once again take up her valuable geological work. But, records Elles, "Unfortunately for geology, that time never came". Instead, with the outbreak of the Second World War, Wood responded again to the call to service. In addition to her committee work, she poured her energies into farming the land attached to her house in Worcestershire, as mandated by the Ministry of Agriculture.

"There is no respite for a farmer in war-time", noted Elles, "In the last year when her head man was away ill for months, she still managed to carry on. It wore her out." Wood died of cancer on 17 January 1946 and, said Elles, “...this great-hearted woman became a war casualty, laying down her life for her country in the Battle of the Home Front."

END NOTES: Sources for this vignette are available online

* Nina Morgan is a geologist and science writer based near Oxford. Her latest book, The Geology of Oxford Gravestones, is available via

www.gravestonegeology.uk 